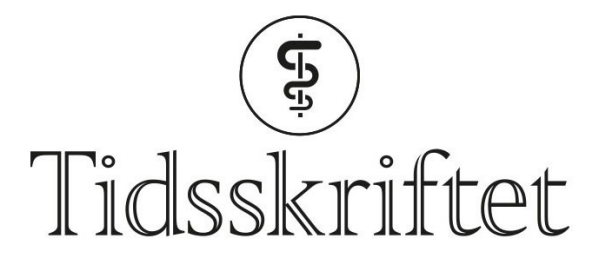

DEN NORSKE LEGEFORENING

\title{
Klimakrisen - vårt ansvar som leger
}

KRONIKK

\section{GUNNAR KVÅLE}

E-post: gunnar.kvale@cih.uib.no

Gunnar Kvåle er professor emeritus ved Senter for internasjonal helse, Universitetet i Bergen og styremedlem i Besteforeldrenes klimaaksjon.

Forfatteren har fylt ut ICMJE-skjemaet og oppgir ingen interessekonflikter.

\section{KNUT MORK SKAGEN}

Knut Mork Skagen er lege i spesialisering i barne- og ungdomspsykiatri ved St. Olavs hospital. Forfatteren har fylt ut ICMJE-skjemaet og oppgir ingen interessekonflikter.

\section{LARS T. FADNES}

Lars T. Fadnes er førsteamanuensis ved Institutt for global helse og samfunnsmedisin ved Universitetet i Bergen og seniorforsker ved Avdeling for rusmedisin, Haukeland universitetssjukehus. Forfatteren har fylt ut ICMJE-skjemaet og oppgir ingen interessekonflikter.

\section{JOHN GUNNAR MALAND}

John Gunnar Mæland er professor emeritus i sosialmedisin, Institutt for global helse og samfunnsmedisin, Universitetet i Bergen.

Forfatteren har fylt ut ICMJE-skjemaet og oppgir ingen interessekonflikter.

De viktigste slag om folkehelsen står utenfor klinikken. Leger har hatt en viktig rolle i kampen mot mange folkehelsetrusler, fra alkohol- og tobakkslovgivning til atomvåpen. $\AA$ bekjempe klimaendringer er en av vår tids viktigste folkehelseoppgaver og krever igjen at leger går på barrikadene.

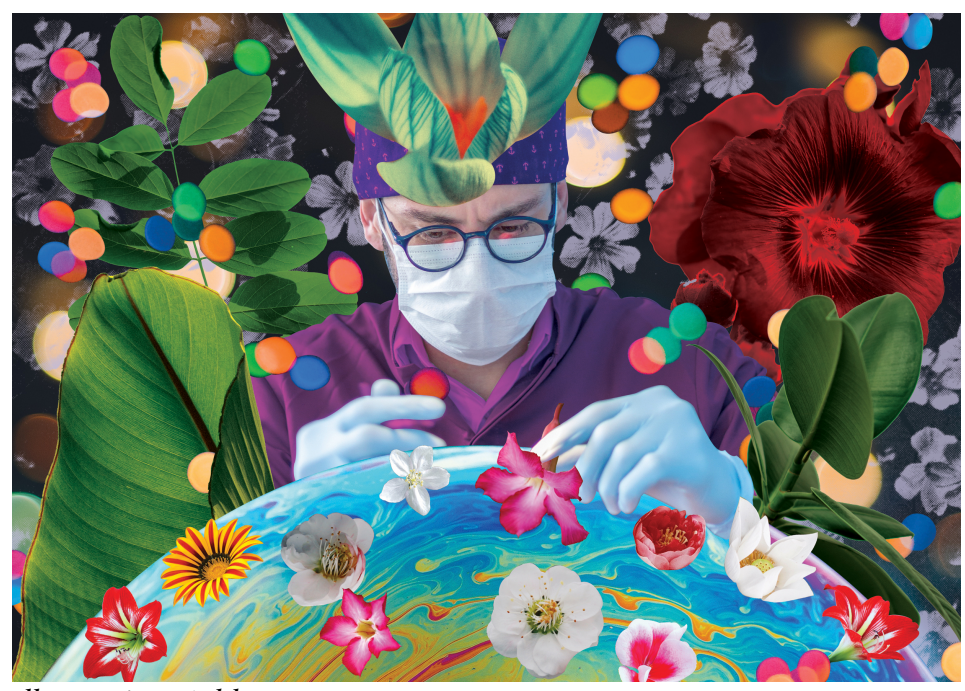

Illustrasjon: Ashkan Honarvar 
Tidsskriftet The Lancet beskrev for snart ti år siden klimaendringene som den største trusselen mot global helse i det 21. århundret (1). Siden har både The Lancet og The BMJ regelmessig skrevet om klimaproblemet. Legeforeningen har også engasjert seg, men det kan virke som den ikke har fulgt opp tidligere initiativer. Knut Mork Skagen skrev i et debattinnlegg i Tidsskriftet i fjor at «Det er meget mulig at Legeforeningen gjør en god innsats for arbeidet mot klimaendringer gjennom foreningens internasjonale samarbeidspartnere, men min opplevelse er at engasjementet er mindre synlig utad enn det var for noen år siden. Politiske og helsefaglige realiteter burde tilsi det motsatte» (2).

Vi mener at det er et imperativ for leger og deres organisasjoner at de påvirker politikere og beslutningstakere med faktabasert kunnskap om nødvendigheten av raske og dramatiske kutt i klimagassutslippene for å unngå en global helsekatastrofe.

\section{Store helseskader}

En økning i klodens gjennomsnittstemperatur fører til helseskade blant annet på grunn av høye dagtemperaturer og hetebølger, kraftigere ekstremvær med tilhørende tørke og oversvømmelser, $\varnothing \mathrm{kt}$ spredning av vektorbårne infeksjonssykdommer og redusert tilgang på mat og rent vann $(3,4)$. Alt nå, ved en global oppvarming på rundt $1{ }^{\circ} \mathrm{C}$, er rapporterte værrelaterte naturkatastrofer mer enn tredoblet siden 1960-årene (5). En hetebølge over Europa i 2003 bidro til rundt 70 ooo flere dødsfall enn i en normalsommer (6). En ekstremt varm sommer i Russland i 2010 medvirket til over 50 ooo dødsfall på grunn av hete og smog (7). Tørke og flom med mangel på rent vann øker risikoen for diaré og andre infeksjoner og bidrar til underernæring og sult, ofte med dødelig utfall blant barn. Alle klimarelaterte dødsfall totalt er beregnet til rundt 400 ooo per år (8).

Med raske og effektive inngrep for å redusere produksjon og bruk av fossile brennstoff er det fortsatt mulig, men svært krevende, å begrense global oppvarming til mindre enn $2{ }^{\circ} \mathrm{C}$ (9-11). Verden er nå på kurs mot en global oppvarming som innen 2100 kan bli på mer enn $3{ }^{\circ} \mathrm{C}(12)$. Med en slik utvikling vil livstruende hetebølger ramme opp til en tredel av verdens befolkning (13). Flere tett befolkede områder i Sør-Asia vil bli utsatt for hete som kan være dødelig for friske mennesker uten tilgang til kunstig avkjøling (14). Dødsfall på grunn av hetebølger er forventet å øke sterkt også i Europa (15). Allerede for perioden 2011-40 er det

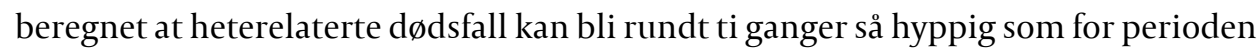
1981-2010.

En oppvarming på nærmere $3{ }^{\circ} \mathrm{C}$ vil føre til en sterk reduksjon av den globale matproduksjonen (13). Fattigdom og sult vil øke, og lokal og internasjonal migrasjon vil nå et omfang vi aldri før har opplevd. Tørken som forventes i Sør-Europa, Sør-Afrika og det vestlige Sahel samt omfattende flommer i Asia, vil, sammen med økt migrasjon, føre til stor risiko for politisk uro og konflikter. Det blir umulig å oppfylle mange av FNs mål for bærekraftig utvikling. Pågående klimaendringer vil ramme alle, men verdens fattige rammes først og kraftigst. Det er et urettferdighetens paradoks at de som har bidratt minst til problemet, lider mest.

\section{Lytt til Attenborough og Thunberg}

FNs klimatoppmøte i desember 2018 (COP24) i Katowice i Polen gir ikke stor grunn til optimisme. Selv om det på møtet ble oppnådd enighet om prosedyrene for registrering og rapportering om hvordan Paris-avtalen skal følges opp, er verden prisgitt hva hvert enkelt land ønsker å gjøre (16). Registrering hjelper lite når nye virkemidler skal rapporteres først på et tidspunkt da det kan være for sent med kraftigere tiltak. I en situasjon der effektiv og rask klimahandling må til, vil en saktegående COP-prosess ikke føre til målet.

Ved klimatoppmøtet gjorde de sterke appellene fra Sir David Attenborough og Greta Thunberg stort inntrykk. Attenborough levnet ingen tvil om alvorligheten i dagens situasjon (17): «Leaders of the world, you must lead. The continuation of our civilisations and the natural world upon which we depend is in your hands.» 
Greta Thunberg, den nå 16 år gamle jenta som før valget i Sverige gikk til skolestreik for klima, kritiserer verdenssamfunnet for 30 år med snakk om tiltak som ikke har virket. Bare effektiv klimahandling kan gi håp (18): «So, instead of looking for hope, look for action. Then, and only then, hope will come.»

\section{Forebygging er alfa og omega}

Leger har et etisk ansvar for å informere om, advare mot og bidra til forebygging av kjente trusler mot liv og helse. Dette gjelder spesielt i situasjoner der behandling blir uoverkommelig hvis forebygging svikter. Vi er nå i en slik situasjon. Uten effektive forebyggende tiltak mot klimaendringene vil konsekvensene for liv og helse bli mer alvorlige enn noe annet som har rammet menneskeheten på flere tusen år. Den store forbedringen av global helse som er oppnådd, særlig i de siste tiårene, vil bli snudd til en helsekatastrofe av uante dimensjoner. I denne situasjonen har vi som leger et spesielt ansvar for å kreve handling som monner nå, uten videre forsinkelse.

Hvis et dødelig virus var i ferd med å spre seg verden rundt, ville en samlet medisinsk ekspertise i Norge og andre land blitt mobilisert for å stoppe alle som med vitende og vilje bidro til en slik spredning. Å spre «klimaviruset» i form av høye klimagassutslipp er derimot fullt lovlig og akseptert av mange av dagens politikere, i Norge og internasjonalt. Dette er tilfellet selv om vi vet at «klimaviruset» blir værende i atmosfæren og kommer til å skade mennesker og annet liv på jorden i mange hundre år framover.

Forfatterne av The Lancets rapport Countdown on health and climate change fra november 2018 utfordrer helsepersonell til å være i front når det gjelder tiltak mot klimaendringer (4). Det samme gjør Andy Haines og Kristie Ebi som i en fersk artikkel i The New England Journal of Medicine peker på at klimasituasjon krever «decisive actions from health professionals» (19).

\section{Grunn for aksjoner}

$\emptyset$ kende engasjement og aksjoner fra leger vil kunne få stor betydning for å svare på denne utfordringen og bidra til forsterket handling. For noen år siden var leger i front i kampen mot tobakksindustrien og økonomiske interesser som fremmet røyking. I november i fjor kunne man i Tidsskriftet lese om legers bidrag til kampen mot atomvåpen gjennom de nobelprisvinnende organisasjonene International Physicians for the Prevention of Nuclear War (IPPNW) og International Campaign to Abolish Nuclear Weapons (ICAN) (20).

Når leger bekjemper menneskeskapte trusler mot liv og helse, beveger legene seg ut over den reaktive rollen som diagnostikere og behandlere. Men en proaktiv handling for å forebygge sykdom og død er en like viktig del av legers etiske og faglige forpliktelser. Som den kjente kardiologen Bernhard Lown sa i sitt nobelprisforedrag da han mottok prisen på vegne av IPPNW i 1985: «... we physicians have taken a sacred and ancient oath to assuage human misery and preserve life. This commitment imposes social and moral obligations for us to band together to make our collective voices heard» (21).

Nettopp ved å gå sammen om et faktabasert budskap kan leger påvirke allmennheten og beslutningstakere til å ta helsetrusler på alvor og sette inn effektive tiltak mot dem.

Nå må legene på nytt stå på barrikadene. Denne gangen for å påpeke at politikk og handlinger som ikke tar kunnskap om klimaproblemet på alvor, utgjøre en alvorlig helsetrussel. Det er behov for sterkere mobilisering i kampen mot økonomiske og politiske krefter som fortsatt støtter produksjon og forbruk av fossile brennstoff på et nivå som fører til irreversible og meget alvorlige skader på mennesker og natur.

\section{Fornyet engasjement av Legeforeningen?}

Det er tegn til et gryende klimaopprør i flere grupper i befolkningen (22). Mange leger er engasjert som enkeltpersoner og deltar aktivt i ulike organisasjoner som jobber mot 
klimaendringer. Klimavalgalliansen ble etablert før valget i 2013 som en felles plattform for foreninger og organisasjoner som aktivt vil støtte klimasaken (23). Det ville vært et tydelig signal om sterkere engasjement hvis Legeforeningen melder seg inn i denne alliansen, der organisasjoner som Naturviterne, Den norske kirkes presteforening, Norges bondelag og mange LO-forbund er med.

Legeforeningen tar også jevnlig stilling til flere politisk relaterte helsespørsmål gjennom policynotater, for eksempel om rusmidler, sunt kosthold og fysisk aktivitet. Om tobakk står det at «Legeforeningen jobber for å oppnå et helt tobakksfritt samfunn» (24).

Legeforeningen har også tatt et prisverdig og klart standpunkt for et forbud mot atomvåpen.

Det er behov for at leger tar en like klar stilling i kampen mot klimaendringene. Vi anmoder foreningen om å styrke arbeidet mot klimaendringene ved å utarbeide en uttalelse med anbefalinger om hva som omgående bør gjøres i Norge for å begrense helseskader knyttet til økt global oppvarming. Legeforeningen bør løfte dette spørsmålet opp som vår tids fremste trussel mot folkehelsen.

\section{LITTERATUR:}

1. A commision on climate change. Lancet 2009;373:1659.

https://www.thelancet.com/action/showPdf?piiSo140-6736\%2809\%2960922-3 (29.1.2019).

2. Skagen KM. Hva skjer med Legeforeningens klimaengasjement? Tidsskr Nor Legeforen 2018; 138. doi: 10.4045/tidsskr.18.o617. [PubMed][CrossRef]

3. COP24 Special report: Health \& climate change. Geneve: World Health Organisation, 2018. https://www.who.int/globalchange/publications/COP24-report-health-climate-change/en/(29.1.2019).

4. Watts N, Amann M, Arnell N et al. The 2018 report of the Lancet Countdown on health and climate change: shaping the health of nations for centuries to come. Lancet 2018;392: 2479-514.

[PubMed][CrossRef]

5. World Health Organisation. Climate change and health.

https://www.who.int/news-room/fact-sheets/detail/climate-change-and-health (29.1.2019).

6. Robine JM, Cheung SL, Le Roy S et al. Death toll exceeded 70,ooo in Europe during the summer of 2003. C R Biol 2008; 331: 171-8. [PubMed][CrossRef]

7. Parry W. Recent heat waves likely warmest since 1500 in Europe. LiveScience 17.3.2011. https://www.livescience.com/13296-european-russia-heat-waves-climate-change.html (30.1.2019).

8. Climate vulnerability monitor. A guide to the cold calculus of a hot planet. 2nd Edition. Executive summary. Madrid: Dara, 2012.

https://daraint.org/wp-content/uploads/2012/o9/EXECUTIVE-AND-TECHNICAL-SUMMARY.pdf (31.1.2019).

9. Masson-Delmotte V, Zhai P, Pörtner HO et al. Global warming of $1.5^{\circ} \mathrm{C}$. Summary for policymakers. Geneve: Intergovernmental Panel on Climate Change, 2018.

https://report.ipcc.ch/sr15/pdf/sr15_spm_final.pdf(29.1.2019).

10. Sauer N. Reality check: is the 1.5C warming target even possible? Climate Home News 9.10.2018. https://www.climatechangenews.com/2018/10/o9/reality-check-1-5c-warming-target-even-possible/ (29.01.2019).

11. Raftery AE, Zimmer A, Frierson DMW et al. Less than $2{ }^{\circ} \mathrm{C}$ warming by 2100 unlikely. Nat Clim Chang 2017; 7: 637-41. [PubMed][CrossRef]

12. WMO climate statement: Past 4 years warmest on record. World Meteorological Assosiation 29.11.2018.

https://public.wmo.int/en/media/press-release/wmo-climate-statement-past-4-years-warmest-record (29.1.2019).

13. Tre forskjellige historier om en varmere verden mot 210o. Faktaark M-1118/2018. Oslo:

Miljødirektoratet, 2018. https://www.miljodirektoratet.no/globalassets/publikasjoner/m1118/m1118.pdf 
(29.1.2019).

14. Im ES, Pal JS, Eltahir EAB. Deadly heat waves projected in the densely populated agricultural regions of South Asia. Sci Adv 2017; 3: e1603322. [PubMed][CrossRef]

15. Forzieri G, Cescatti A, E Silva FB et al. Increasing risk over time of weather-related hazards to the European population: a data-driven prognostic study. Lancet Planet Health 2017; 1: e200-8.

[PubMed][CrossRef]

16. Aftenposten mener: Katowice viktig, men ikke nok. Aftenposten 16.12.2018.

https://www.aftenposten.no/meninger/leder/i/3j8mXM/Aftenposten-mener-Katowice-er-viktig_-men-i kke-nok(30.1.2019).

17. Attenborough D. Address to COP24. Video 7.12.2018. https://www.youtube.com/watch?vkqVPFpJAwSo (30.1.2019).

18. Thunberg G. The disarming case to act right now. TED-talk. TEDxStockholm 2018. https://www.ted.com/talks/greta_thunberg_the_disarming_case_to_act_right_now_on_climate (30.1.2019).

19. Haines A, Ebi K. The imperative for climate action to protect health. N Engl J Med 2019;380: 263-73. [PubMed][CrossRef]

20. Mæland JG, Akhtar SN, Hilt B et al. Atomvåpenforbud, nobelpris og legers innsats. Tidsskr Nor Legeforen 2018; 138. doi: 10.4045/tidsskr.18.0452. [PubMed][CrossRef]

21. Lown B. Nobel Peace Prize lecture. A prescription for hope. N Engl J Med 1986; 314: 985-7.

[PubMed][CrossRef]

22. Besteforedre mot global oppvarming. Tid for klimaopprør.

https://www.besteforeldreaksjonen.no/2019/o1/tid-for-klimaoppror/ (30.1.2019).

23. Klimavalgalliansen. http://www.klimavalgalliansen.no/(30.1.2019).

24. Den norske legeforening. Fjern tobakken. Policynotat nr. 2/2018.

https://legeforeningen.no/Emner/Andre-emner/Publikasjoner/policynotater/Policynotater-2018/Fjerntobakken/(30.1.2019).

Publisert: 2. mai 2019. Tidsskr Nor Legeforen. DOI: 10.4045/tidsskr.19.0o81

Mottatt 25.1.2019, første revisjon innsendt 3.2.2019, godkjent 7.2.2019.

(C) Tidsskrift for Den norske legeforening 2020. Lastet ned fra tidsskriftet.no 